\title{
The Buddhist Real Concept of Peace in Theory and Up Wards (Paṭisotagāmī) Practice Which Towards on Philosophical Revelation
}

\author{
Wadigala Samitharathana Thero
}

Undergraduate (BA Hon. Philosophy); Royal Pandit (O. S. S.), Department of Philosophy, Faculty of Arts, University of Peradeniya

\begin{tabular}{l} 
ARTICLE INFO \\
\hline Keywords: \\
Attitudinal Chang \\
Harmony \\
Ideology \\
Morality \\
Social Consciousnesses
\end{tabular}

\section{Introduction}

Buddhism has long been celebrated as a religion of peace and non-violence. With its increasing vitality in regions around the world, many people today turn to Buddhism for relief and guidance at the time when peace seems to be a deferred dream more than ever, with the wars in the Middle East and Africa, and the terrorist activities expanding into areas where people never expected that scope of violence before such as Bali, London, and New York. Yet this is never a better time to re-examine the position of Buddhism, among those of other world religions, on peace and violence in the hope that it can be accorded in the global efforts to

\begin{abstract}
In a fast-changing world different social institutions and organizations have emerged in order to maintain the well-being or the harmonious existence of human beings and much contribution has been done in the maintenance and the promotion of well-being of humanity. However, the modern era with its rapid developments confronted with many challenges such as environmental pollution, serious health issues, population growth and scarcity of food \& sheltered specially the direct man-made issues related to the peace and co-existence of humanity. As a result, physical, social, mental and spiritual well-being has been greatly affected and damaged. Buddhist teachings emphasize that peace is dependent on the physical, social, mental and spiritual well-being of individuals living up wards in any society. Thus, it signifies a state of harmony and friendship, calmness and quietness and also the freedom from war and violence.

Hence in the achievement of harmony and peace most significant is the identification and verification of the fundamental issues with impartiality, justice and honesty that lead to the warfare between the nations or countries which is the Buddhist standpoint. In the modern world warfare takes place from many aspects. They have been able to avoid such which is the only fact that humanity can be proud of in this civilized world. However, the situations within some countries are not satisfactory especially in some Asian and Middle East countries where there is divesting warfare between the divided groups who have the underhand support by the powerful.

Such lead to the attitudinal change in the people where as their social consciousness becomes widened and deepened. Thus, the attitudinal change gradually takes place which is the key factor for lasting peace in the sustainable developmental countries. Thus (a) Respect for morality (b) Attitudinal change (c) Widening of social consciousness (d) Establishment of higher ideals are the key elements found in Buddhist teachings in theory and upwards practice.
\end{abstract}

* Corresponding Author E-Mail Address: samitharathana23@gmail.com 
create new sets of values regarding the ways people manage conflict and maintain peace via nonviolent means.

This research paper tends to provide a review of the Buddhist vision of peace in the light of peace studies. It also addresses the Buddhist perspective on the causes of violence and ways to prevent violence and to realize peace. The last section explores the potentials of

\section{Context}

Buddhist contributions to the peacemaking efforts and the promotion of a culture of peace in today's world. Buddhism, having enjoyed a long history and enrichment by generations of people in various traditions, ranges north and south with branches across many cultures and regions. However, a common core of Buddha's teaching and practice is observed in major Buddhist traditions and considered essentials of Buddhism. In this article, the term Buddhism is used to refer to the common core teachings across the current major traditions of Buddhism.

\section{1 The Concept of Peace in the Buddhist Worldview}

Buddhists believe that the Buddha (meaning "the awakened") awakened to the laws of the universe, which are said to be operating eternally, whether the Buddha discovered them or not. The most fundamental among these laws is the law of karma, or, in Buddhist terminology, dependent origination, which explains the genuine condition of things that exist in the universe. In its simplest straightforward form, dependent origination claims that anything (including sentient and insentient beings) can only exist in relation to everything else; if the causes of its existence disappear, then it ceases to exist. Nothing can exist on its own and everything is dependent on other things. All elements, all entities, all phenomena are thus related directly and indirectly to one another in the universe. Any change in this huge interconnected compound of existence would definitely, eventually exerts influence on everything else. Derived from the principle of dependent origination is the Buddhist view of the cosmic world and the human being.

At the macro level, the universe is represented and seen from a Buddhist viewpoint as a network of jewels, an interconnected and interdependent web of nodes, each of which simultaneously reflects all other hundreds of thousands of nodes in the web. All other nodes would simultaneously reflect this specific node. This network is named "the Indra's Net" in the Avatamsaka Sutra (Taisho 9: 278). Each node can contain another web-like universe within itself and so forth with an infinite number of webs, i.e. universes. In this vast, endless cosmos, everything is still interrelated even in the most remote sense.

Down to the micro level, the human being is viewed as a string of processes governed by the principle of dependent origination. Since everything within a human being (including physicality and thoughts) depends on other things to exist, nothing within this human being is genuinely independent (autonomous). This doctrine of no-self (Pali: anatta; Skt. anatman), however, does not rule out the existence of temporary aggregates capable of responding to environmental stimuli, i.e., our body and mind. Also, it recognizes the diversity among all beings and the uniqueness of each since each being undergoes constant changes while responding and reacting in its own way to all other beings and things around. The everchanging quality in any beings denotes a vast capacity for change and development possible in either directions, for better or worse. Yet the potentials to transform the status quo are always looming in the horizon.

The principle of dependent origination and the Buddhist view of the universe and the human beings undergird an imperative for people who realize the interdependent nature of their existence and the interconnection among all things - they would develop a strong sense of responsibility for their own behaviors, as well as appreciation and empathy for others. It is from this realization of the true nature of existence that non- harming, compassionate, altruistic 
action would arise. In the openings of many sutras, the Buddha, the one who awakened to the cosmic reality, is described as naturally expounding four basic mental faculties (Brahmaviharas, "Divine Abidings"; also named appamanacetovimutti, "immeasurable deliverance of mind"): loving-kindness (metta), compassion (karuna), sympathetic joy (mudita), and equanimity (upekkha). The Buddha teaches that these four mental faculties, together with the Four Noble Truths, are to be cultivated by all bhikkhus (Skt. bhiksus) and later all Buddhists through reflecting upon the sentient beings of infinite numbers who are on their way to become a buddha (see Taisho 1: 26). Yet the altruistic mental faculties are combined with the wisdom developed along with the gradually deepening reflection. This is the guiding principle of all Buddhist practices - the middle way. Through these mindful actions conducted with moderation can an ideal Buddhist state of existence come true-living in harmony with everything (sentient or non-sentient) in the universe.

This Buddhist way of looking at the world comes, in the opinion of Johan Galtung (1993: 23), a Norwegian peace studies pioneer, closest to the one dynamic, complex peace theory he proposes, in which the world is "precisely a process based on diversity in symbiotic (mutually influential) interaction." In this world of multi-leveled plurality, according to Galtung, peace is not a stable, end state but a more interactive process of a series of changing and balancing acts, an on-going dialectic between our actions and the world. This contingent view of peace, as shared by many peace scholars and activists in the field, is similar to what Buddhist perceives peace to be. In fact, the complexity and the collectiveness in causes leading to peace or war have long been recognized in the morphological construction of those words. According to Sanskrit dictionaries (Hirakawa, 1997; Ogiwara, 1979), the words samnipata, samgri, and samgama, all refer to the concept of peace. These words share the root sam-vii meaning people do things together, which is also shared by the Sanskrit word referring to war (samit). On the basis of this morphological derivation, both peace and war are produced by the collective, rather than individuals. No single nor simple explanation of what builds peace or create war would suffice.

The view of peace as a collective product is well in line with the Buddhist worldview based on the principle of dependent origination which emphasizes the mutual influence of all the elements involved in any situation. With this interdependent frame of reference, Buddhists would prefer a holistic view of peace, instead of peace in separate contexts such as schools, families, or the environment. This is again very close to what many peace studies scholars have advocated as the ultimate vision of peace (Brock-Utne, 1997; Galtung, 1993; Galtung \& Ikeda, 1995; Turpin \& Kurtz, 1997). From the holistic perspective, the connection between the concept of negative and positive peace becomes clear and imperative in the light of the Buddhist law of nature, dependent origination. Absence of war and direct violence only constitutes a temporary peace if there is no justice present in the socio-economic international structure. The injustice and the violence causing suffering in every other node in the web of existence would inevitably and eventually weigh the negative peace away. Though the negative peace is only temporary, unstable and fragile, it is absolutely indispensable on the way to the positive peace. Since each human being and each level of systems are interconnected, to create a positive peace compels efforts of everyone at every level of human structures. The Buddhist view of the interconnected world demands that the ideal of world peace is less rhetoric at the negotiation tables among some "superpowers" in the international level than starting a personal transformation of one's daily living. And this peacemaking effort is a continued striving at every very moment because of the dynamic, constant changing nature of all the possible causal forces in this world. 


\subsection{Buddhist Perspective on Causes of Violence/Conflict/War}

Buddhism, being a religion with a claim of the reality of existence, has well acknowledged causal forces that could constitute the hindrance to a harmonious living on every level of human actions. Violence and conflict, from the perspective of Buddhist principle of dependent origination, are, same with everything else in the world, a product of causes and conditions. To eliminate violence and conflict, all we have to do is to resolve the underlying causes and conditions. Using human body/consciousness as a division, the Buddhist analysis of the causes of violence and conflict is arrayed along three domains: the external, the internal, and the root (Shih Yin-shun, 1980).

\subsection{The External Causes of Violence and Conflicts}

The Buddha looks at the external causes of conflict as consequences derived from a general orientation common to all living beings: avoiding harm and obtaining happiness. Anything contrary to this would result in disturbing one's peace and lead to conflict. If people want to live an ultimately happy life with no harms toward themselves at all, the Buddha teaches, they should start with avoiding causing harm to others, physically and verbally at the personal level, since people are afraid of physical violence and resent harsh words; and the physical and verbal harm we inflict upon others usually leads to hate and conflicts that, in turn, would bring harm to us and cost our happiness. As stated in one Buddhist Scripture,

All fear death.

None are unafraid of sticks and knifes.

Seeing yourself in others,

Don't kill don't harm

(Dhammapada, 18; translated by the author from Taisho 4: 210).

Bad words blaming others.

Arrogant words humiliating others.

From these behaviors

Come hatred and resentment.

Hence conflicts arise,

Rendering in people malicious thoughts

(Dhammapada, 8; translated by the author fromTaisho 4: 210).

And these malicious thoughts would, in due term, result in harm upon us since none are really exempt from the influences of all others, including the people we harmed. The Buddhist principle of dependent origination crystallizes the imperative of many peace workers' advocacy for nonviolent interpersonal communication and interactions as they are indispensable to what human pursue - a life of happiness. That is, practicing nonviolence in speech and action would ultimately benefit the practitioner.

In larger contexts, Buddhism recognizes the indirect form of violence in the social systems to be external causes of conflicts as well. Violence, conflict and war caused by injustice in political and economic structures bring even more harms to people on a grand scale (Shih Yinshun, 1980; Sivarksa, 1992; Sumanatissa, 1991). How to promote human rights and equality along the social, legal, political, and economic dimensions of our collective structures, not for the benefits of ourselves but for all's, thus becomes part of the Buddhist mission to eliminate the potential causal forces of violence and peace. Recognizing the material needs for sustaining human living, Buddhism postulates the principle of Middle Way as a criterion in making decisions on all levels of activities and encourages frugality as a positive virtue. The relentless pursuit of economic development and personal property regardless of environmental or moral 
consequences is considered not in accordance with the Middle Way since it destroys the balance between consumption and resources, as well as material gain and spiritual growth. The Internal Causes of Violence and Conflicts

Albeit external verbal and physical wrongdoings as well as social injustice are causing conflicts and violence, Buddhism contends that these behaviors and structures originate all from the state of human mind, since the violence and injustice are responses toward external stimuli produced by people's inner mind operation. That is, the deeper causes of any conflict lie internally in the mental operations within each being. For example, confronted with the threat of physical and verbal harm, it is natural for us to feel fear, dislike, resentment, anger or hate. Out of this negative caste of mind, we would again resort to a violent response, and hence a conflict arises. Similarly, institutions or groups would respond to adversity with establishing policies or laws trying to protect whatever interest they perceive to be under threat or attack, which would cause conflicts since others' interest and well-being might be undermined by these measures. In other words, physical and structural violence are the product of human mental status such as fear, anger, and hate, which are considered in Buddhism to be the internal causes to violence and conflicts.

Even when no threat of personal safety or collective interest is in presence, conflicts may occur, from the Buddhist perspective, as a result of our two major mental attachments to, first, subjective views, opinions and, second, the desire for materials, relationships. The stronger the attachment is, the more obsessive one would be, the more extreme behaviors one would engage, and the more severe the conflict would become. The attachment to views refers to insistence on the correctness of one's own views, ideas, and ways of doing things. It would elapse into prejudice, polarity, negating other views and ways of life and ultimately negating people who are different from "us". The Buddha sees this attachment to difference as one major cause of in-group and inter-group conflicts. Two thousand years later, this has also been identified by modern scholars as central to conflicts between ethnic, social, religious groups and individuals (Blumberg, 1998; Myers, 1999). The second major cause of conflicts, the attachment to desire, refers to want for material goods and longing for affection and belonging in human beings. It can easily go beyond the level of necessity and become greed. The greedy desire to have and to own drives individuals, groups, and nations into competition for what they want, followed by conflicts and even wars. As depicted in Vibhasa-sastra:

For the sake of greedy desire, kings and kings are in conflict,

So are monks and monks, people and people, regions and regions, states and states (The Middle Length Discourses of the Buddha, Taisho 28: 1547).

This competition is discerned by the Buddha as a lose-lose situation: If we win, we incur resentment toward ourselves.

If we lose, our self-esteem is hurt (Dhammapada, Taisho 4: 210).

None benefits from this competition derived from greediness. Even winners accrue negative feelings from the lost party that inevitably plants seeds of future conflicts. The internal cause of violence and conflicts as analyzed through a Buddhist perspective, corresponds to many peace educators' emphasis on intrapersonal peace building and the United Nations' campaign for a culture of peace. The focus on individual and inner transformation of attitudes on and interpretations of what happens externally, which in turn would motivate appropriate change in behaviors, is considered more effective in eliminating the causes leading to violence and conflicts on all levels of human interactions.

\subsection{The Root Cause of Violence and Conflicts}

Behind the mental, behavioral and structural causes of violence and conflict, Buddhism goes even further to the ultimate fundamental cause leading to all the suffering inflicted by violence and conflict. Buddha attributes all our attachments, the resulting harming behaviors and the 
suffering hence caused, to the human ignorance (avijja), that is, we can not see the world as it is and see our self as such. We are ignorant to the cosmic reality that everything in the world is inter-related, interdependent. Not adopting the Buddhist worldview, we thought we are separate from others as an independent entity: our views are different from theirs; our properties are certainly not theirs. Hence we develop our attachments to views and desires through the reinforcing notions of "me" and "mine." We are not impartial in looking at things. We tend to focus on the harm that is done to us, instead of examining the whole event in its context with all the causes and conditions conducive to its happening. This ignorance to the principle of dependent origination alienates us from what really happens in the situation and the complex set of conditions around any given event, and thus rids us of the possibility of making correct assessment of the event and react accordingly in time. Without the lucidity to discern the causes, development and effects of specific events, we are inevitably causing conflicts and doing harm to others as well as ourselves all the time. Even wars between states come out of great fear and the collective ignorance (Thich Nhat Hanh, 2003). This ignorance is what Buddhism identifies as the very root cause of violence, conflict, and war, which prevents human beings to live a peaceful life.

\subsection{Approaches to Peace in the Buddha's Teaching}

The Buddha's teaching, though encompassing a wide range of complex belief systems, started with the Buddha's first preaching which is conventionally equated with the essence of his teaching - the Four Noble Truths (catur-aryasatya). The first two truths discern the Causes of violence and conflict and the suffering caused thereby: First, life inevitably involves suffering/dissatisfaction (duhkha-satya); and Second, suffering/dissatisfaction originates in desires (samudaya-satya). The third and the fourth prescribe the cure for this unpleasant way of living, that is, how to promote a peaceful way of living and ultimately live in peace: Third, suffering/dissatisfaction will cease if all desires cease (nirodha-satya); and Fourth, this state can be realized by engaging in the Noble Eightfold Path (marga-satya). In fact, all the Buddhist practices are de veloped in accordance with the Four Noble Truths; that is, they are designed to enable people to alleviate this suffering and to realize a peaceful state of existence at all levels. In this section, the Buddhist approaches to peace can be categorized in four dimensions in the holistic/integrated model of peace in the field of peace studies: intra-personal, interpersonal, in-group, and inter-group.

\section{- Insightful Reflection as the Practice of Intra-personal Peace}

To achieve peace within a person, the Buddhist approach is to observe and reflect upon the conditions in the external and mental operations, and then to decide on the most appropriate course of action as response to the outer and inner environments. With the most adequate response, we would not do harm to ourselves as well as not harbor negative feelings and thoughts toward other. Before taking any external action to realize peace, the first step for any Buddhist would be to look at ourselves and the events happening around us carefully and honestly, "not sugarcoating anything about the realities of life, consciousness, or culture" (Sivaraksa, 1999: 42). The greater urgency placed by Buddhism upon the inner reflection finds its doctrinal basis on the Buddhist analysis of the roots of violence and conflicts within the mind. As the Buddha teaches,

You should carefully guard your mind,

Maintaining the mindfulness all the time,

In order to cease conflicts

(The Middle Length Discourses of the Buddha, Taisho 1: 26).

This is the starting point for the Buddha's disciples to live in peace since peace depends not so much on what happens to people, but on what attitude, comprehension, and response they give 
to the happenings. An understanding of the complex set of plural forces, causes and conditions that have brought the event into being and have shaped our immediate perception of, feelings for, and reaction to the event, only comes possible from the insight (vipassana) we develop from inner reflection in the light of the principle of dependent origination. As the Buddha testifies,

Once I dwell in peace (= awakened to the universal), In adversity I react with no anger;

Living among angry people,

I act with no anger (Dhammapada, Taisho 4: 210).

With a clearer view of what happened through practice of inner reflection, we are empowered with proactiveness; that is, we no longer would respond compulsively, but would be capable of choosing a course of actions more appropriate and beneficial to all parties involved, with no anger or hate harbored within ourselves.

This approach does not only work on the personal level, many contemporary Buddhist leaders of peace movements give first priority to inner transformation within individuals on the path to peace in larger contexts. The Venerable Thich Nhat Hanh (1999: 159) encourages people who would like to engage themselves in peace activism to prepare themselves in advance by developing awareness and mindfulness for practicing peace, that is, reacting "calmly and intelligently, in the most nonviolent way possible." Inner practice on nonviolence is hence considered a prerequisite to peace workers and educators. Further relating the impact of individual practice to the whole picture, the Venerable Shih Sheng-yen (1999: 175) stresses the influence of few on many, in that "peace in society begins with peace within oneself", since the widening circle of influence of each individual would expand from their immediate sphere gradually to the larger contexts. Without this "internal disarmament" (as The Dalai Lama called it; see Hopkins, 2000: 194), our negative emotions derived from the ignorance to the true operating principle behind all phenomena (including our own feelings and thoughts), the fear, anger and confusion in the state of mind, would rise as reactions to the adversary conditions, and would prevent us from acting nonviolently and living harmoniously with other people in the world.

In addition to ridding ourselves of the negative, non-peaceful feeling and thoughts within us, through the practice of reflection upon the dependently originated reality (i.e. seeing and experiencing the interconnections and mutual dependence that run through everything in this world), concerns for other beings would evolve and slowly become as natural as concerns for self in the process. Such conceptions would facilitate the cultivation of four positive emotional faculties (Pali: appamañña or Brahmavihara): metta (loving-kindness), karuna (compassion), mudita (sympathetic joy), and upekkha (equanimity). These pro-social qualities derived from the understanding of the interdependent reality would compel a natural drive for altruistic actions:

The one who dwells in compassion would not have a conflictual volition;

The one who dwells in loving-kindness would always act most appropriately (Dhammapada, Taisho 4: 210).

Though internally generated, these positive, prosocial qualities contain an outward orientation. That is, the interpersonal practice of insightful reflection is closely connected with the external practice of nonviolence and mutually enhances each other since the inner nonviolence and peace would be manifested in the five precepts, the fundamental code of conduct for all Buddhists to live in harmony with other beings in the world.

\section{- Five Precepts as Practice of Interpersonal Peace}

In the Four Noble Truths, the Buddha pointed out the human predicament and its root cause, and then sets forth the Noble Eightfold path (Pali: ariya atthangika magga) for his disciples to strive for enlightenment (Skt. nirvana; Pali: nibbana). The Noble Eightfold Path is the Buddhist 
training system leading toward the final realization of nirvana, which composes of eight divisions: right understanding, right thought, right speech, right action, right livelihood, right effort, right mindfulness, and right concentration" (Rahula, 1974: 45).

For his lay followers (those who do not join the sangha), the Buddha prescribes the Five Precepts (pañcha sila) as the minimum moral obligations for living a harmonious life in the secular society:

1. to abstain from taking life

2. to abstain from taking what is not given

3. to abstain from sensuous misconduct

4. to abstain from false speech

5. to abstain from toxicants as tending to cloud the mind (Buddhaghosa's Papancasudani Sutta, in Buddhist Scriptures, 1959: 70).

Following the Precepts would prevent violence toward self and others by no wrongful acts on physical (1 \& 5), economic (2), familial (3) and verbal (4) levels in interpersonal interactions, which is essential to any peaceful living. Among contemporary efforts toward peace, the Five Precepts are hailed by many peace scholars and activists as the daily practice of peace (e.g., Chappell, 1999; Kraft, 1995). Galtung (1993: 117) contends that the absolute rejection of committing direct violence as prescribed in the Five Precepts is the "basic contribution of Buddhism in the creation of peace". In fact, many components of today's conflict prevention program in schools and communities have the Five Precepts incorporated.

Furthermore, an extended definition of the Precepts would yield even wider application into the social structures in which injustice prevails. For example, in the second precept, 'to abstain from taking what is not given,' lays the imperative against structural violence, the violence that harms or oppresses people slowly, indirectly since it was built into a structure or an institution, such as economic exploitation or distribution injustice. If people could develop first awareness of this large-scale theft of non- conventional nature, this awareness would then enable them to organize and mend the situation.

In the effort striving for enlightenment (the Buddhists of all branches) as long as they observe the second precept, secular-economic development and spiritual quest can according to Schumacher (1975): to utilize and develop one's faculties, to overcome one's ego-centeredness by working with others, and to bring forth the goods and services needed for existence. Only work in line with the Precepts is the right livelihood, which hence excludes butchery, production of and trade in armaments, intoxicants, slaves and prostitutes, and any economic activities taking what is not given or given in a dishonest way. Not only guiding people to assume economic obligation to the society, this requirement also echoes the peacemakers' protest against the humongous military- industrial-economic compound in today's global economy.

\section{- Six Principles of Cordiality as the Practice of In-group Peace}

The Buddha's disciples (monks and, later, nuns) live a communal life since the Buddha does not encourage monks and nuns to live in solitude all the time, hence without opportunities to cultivate the four immeasurable deliverances of mind, loving-kindness, compassion, sympathetic joy, and equanimity. Within any groups, including Buddhist ones, exists the possibility of disputes and conflicts. To prevent harm and suffering caused by disputes and conflicts among people, the Buddha teaches the six principles of cordiality (Pali: cha dhamma saraniya) that would "create love and respect and conduce to cohesion, to non-dispute, to concord, and to unity" (Kosambiya Sutta, 6, The Middle Length Discourse of the Buddha: 420) in a community. Similar to other Buddhist codes of conducts that aim at cultivating inner states of mind as well as regulating external behaviors, the principles of cordiality prescribe that in private and in public, one maintains 1) bodily acts, 2) verbal acts and 3) mental acts of loving- 
kindness toward other group members, 4) shares material gains with others, 5) follows the same codes of conducts, and 6) holds the same view that would lead "one who practices in accordance with it to the complete destruction of suffering" (Kosambiya Sutta, 6, The Middle Length Discourse of the Buddha: 421).

While the first three principles focus on the direct impact of individual group member's acts upon other members, the last three refer to the indirect structural and cultural impact. The fourth principle, equally sharing material goods with each other, denotes a fair distribution of resources among members within a community. The economic and financial justice could further reduce the attachment to material and monetary possessions as a root cause of conflicts. The fifth one, following the same codes of conducts, refers to the regulations of an organization, or legal systems in a nation-state. The Buddha also demands that the regulations should be "not misapprehended, justly, unbiasedly stipulated with the purpose to completely alleviate suffering" (The Middle Length Discourse of the Buddha: 420-1).

The last principle, sharing the same view, deals with the deviance in opinions among group members. In the Buddhist sangha, sharing the same view does not mean ruling out the diversity or disagreement (for examples, see the Kinti Sutta, The Middle Length Discourse of the Buddha: 103.4ff; and the Bhaddali Sutta, The Middle Length Discourse of the Buddha: 65.7ff). In the original sangha operation, when disputes arise, social harmony within the community is built on small group dialogue in which diversity can be expressed and discussed. At the same time, through dialectic exchange in the assemblies, members would find and confirm their common ground resorting to the ultimate goal of complete destruction of suffering. In the scripture (Mahaparinibbana Sutta, The Long Discourses of the Buddha: ii.154), the Buddha places a high value on these meetings. In the seven criteria he uses to evaluate the social strength of each monastic order, holding regular and frequent assembly meetings is ranked as first, the primary criterion. And the second criterion states that sangha members are supposed to conduct their business in harmony during the meetings. To ensure fairness and harmony, the sangha assembly meeting procedures, recorded in the Vinaya (For example, in Taisho 22: 1428 and Taisho 23: 1438), depict a democratic nature of these meetings - shared authority, distributed responsibility, balanced participation, and decision aspiring to consensus (Chappell, 2003; De, 1955; Khongchinda, 1993; Thich Nhat Hanh, 2003).

These procedures are very similar to those advocated by conflict management and organizational communication scholars of our own time. Many peace education activities engaging people in participatory decision-making, problem-solving, consensus building and open discussion bear a remarkable resemblance to what Buddhist bhikkhus have been doing in their assemblies since the days of the Buddha (for examples of modern training activities, see Macy, 1983; Schilling, 1993; Schroeder, 1995). This is no coincidence at all, since the genuine benefits of small group operation as the basis of organizational harmony have been well documented in the field of sociology, economics and anthropology (Chappell, 1999; Galtung, 1990; Loy, 2002; Myers, 1999; Schumacher, 1975; Turpin and Kurtz, 1997).

Recognizing the benefits of small group operation within a larger context, a peace activist in Thailand, Sulak Sivaraksa, forms small groups of social relief supporting orphaned children, single mothers, ecological concerns or inter-religious cooperation. His work is now expanding to include micro enterprises and more than 400 micro banks, improving the economic and social conditions of hundreds of thousands of Thai people (Sivaraksa, 1992, 1999). This bottom-up Buddhist approach stresses open communication and interdependence among group members and even across group lines onto the inter-group and organizational level, which can also be seen in other Buddhist organizations, such as the Tzu-Chi Foundation of the Venerable Cheng-Yen in Taiwan and the Japan-originated Soka Gakkai International led by Daisaku Ikeda. 


\section{- Nonviolence Intervention as the Practice of Inter-group/International Peace}

In the inter-group or international affairs, the Buddhist insistence on dialogue and nonviolence still rings true. The Buddha once tells a story of the King of Longevity to illustrate his stance on war and retribution while facing violence or foreign invasion. In the story, the king, when his country was invaded by another king, gave up the armory defense to protect the lives of his people. He also asked his son not to seek revenge for the brutal death of him and his wife. Later, when the son had three opportunities to kill the enemy king, he did not do so, following his father's last words, and explained everything to the enemy king. The enemy king, deeply moved, regretted his past wrongdoing and returned the land he had invaded. As the moral of the story, the Buddha concludes that "if one seeks retribution for vengeance through vengeance, the chain can never be broken" (Taisho 1:26). This emphasis on absolute nonviolence is exemplified in the Buddha's intervention while his home country of the Sakyans was to be invaded by a neighboring country. The Buddha in his old age sat at the border of the two kingdoms to try to talk the warlike king out of his plan. His persuasive argument successfully convinced the king for two times but the third time he failed. The king marched his army and killed almost all the Sakyans who, following the Buddha's teaching of not taking life, did not fight back at all. Yet the story did not end in a negative tone since the principle of dependent origination was brought in and the causes and conditions leading to the horrific suffering of the Sakyan clan were explained (Taisho 2: 125).

This absolute insistence on non-violence in the face of violence has incurred criticism of Buddhism being passive pacifism which could not prevent human suffering. Yet a very recent event may add a more positive angle to the nonviolence principle in practice. For the first time in ten years, China resumed dialogue with a delegation from Dharamsala's Tibetan Government-in-Exile in September 2002. The Dalai Lama has long insisted on peaceful means in dealing with China on the sovereign of Tibet. His unwavering commitment to non-violence has accrued worldwide respect and sympathy for the Tibetan people. Instead of expressing anger and determination in seeking revenge, the Dalai Lam found common ground with the Chinese by recognizing that the Chinese are just like him - wanting no suffering but happiness, and they are also conditioned by the principle of dependent origination as the Tibetan people (Chappell, 2003).

His insight into the current situation and his capacity to empathize with the perpetrators have enabled him to find alternative ways of responding to the harms and damages done to the Tibetan people. The Dalai Lama advocated a "Middle Way" for Tibet: not full independence but self-governed by a democratically elected government, as well as vision of Tibet as a Zone of Ahimsa (Herskovits, 2002: 5). The latter refers to "a sanctuary of peace and nonviolence where human beings and nature can live in peace and harmony" (the Dalai Lama, 1989). In this vision of Tibet, based on the guideline of ahimsa (non-harming), no manufacture, testing or storage of armament is permitted. The entire land is to become designated a national park where animals, plants and natural resources in the ecosystems are protected against exploitation. No technologies producing hazardous wastes would be developed (Powers, 2000). And this persevering effort is finally met with a positive reaction from the other overwhelmingly powerful party, as the leading representative of the delegation visiting China "said he was impressed by the flexibility of the Chinese" (Herskovits, 2002).

What the Dalai Lama practices and achieves not only demonstrates a realistic alternative to the international politics but also provides a living proof of the feasibility of the Buddhist principle of peace in today's world that is very different from the one Buddhism evolved. From the intrapersonal to the international, Buddhist approaches to peace at different levels can be well situated in an integrated model of peace building and peace keeping in the contemporary world (the Dalai Lama, 2001, 2002). As the integrated peace is often criticized to be too much an umbrella term spanning too wide a spectrum, the feasibility to achieve such a vision of peace 
is doubted. The Buddhist approaches to peace can substantiate this model of peace by proving that nonviolence does work and can strengthen the beliefs that absence of violence is never productive without non-violence practiced at all levels of human activities.

\section{- Translating Buddhism into Peace Research and Activism}

To explore new dimensions of peacemaking and peacekeeping, as peace researchers do all the time, is to reflect back upon one fundamental of human culture - religious traditions and beliefs. This need is more pressing than ever since we live in a world of plural religious traditions that, from time to time, are accredited as causing conflicts, even wars. Buddhism with its worldview characterized by dynamic interdependence and its behavioral codes stressing non-violence and loving-kindness offers rich resources for peacemaking techniques. For example, the extended six principles of cordiality could be the ideological buttresses that many peace activists need in resistance against the structural violence (Cabezón, 1999; Galtung, 1990). Furthermore, in examining the development in the field of peace studies, the Buddhist worldview is surprisingly in accordance, and hence worthy of further studies in at least three areas: the process-oriented paradigm, peace by peaceful means, and the micromacro linking in a holistic framework of peace.

\section{- The Process-Oriented Paradigm}

The Buddhist principle of dependent origination mandates a world composed of dynamic exchanges and interconnections among all entities existing in the world. The complex web of causes and conditions in any given event engenders a focus on process and causes, over a focus on end results. In the past, peace used to be reified as an absolute ultimate: transcendent, idealistic, and thus unreal, unattainable. People worshipped peace with awe but knew deeply in their hearts that peace is unlikely to be realized in this world. Nowadays, most peace researchers agree that peace is no more a stable state to be reached at the end of the tunnel, but a composite of dynamic interactions demanding continued striving because of the constantly changing conditions of all forces/factors involved. Therefore, in efforts to build peace, seemingly not directly relevant factors and conditions conducive to peace could be just important as conflict resolution or other direct intervention measures in dealing with conflicts. This new way of looking at peace building and peacekeeping is in perfect accordance with the Buddhist worldview, as substantiated by the Sanskrit morphology of words referring to peace and war as collective products.

The positive orientation and the shift to cultivating causes of peace and preventing causes of violence bring a new focus to peace work. By working with everyday, mundane issues regarding interpersonal relations, human rights and the environmental concerns, peace activists are advancing on both the direct and indirect causes of peace; in other words, they are creating peace and furthering the realization of a culture of peace at every moment. Even if peace makers seem to do little about the immediate and direct violence in their surroundings, this process-oriented perspective empowers those who strive for peace, especially in those war-torn regions of the world such as Croatia, Israel ("Peace: How realistic is it?", 2003), and Northern Ireland (Stewart, 2002), where people might feel helpless, powerless when only small changes toward peace can be produced in a conflict and violence-ridden environment.

While the process view of peace has been embraced by many peace activists and educators, its full implications for peace research is yet to be explored. Johan Galtung is among the first scholars that have incorporated the Buddhist perspective into his peace research, which is most obvi ous in his works after the 1980's (Lawler, 1995). To Galtung (1993, 1990), the Buddhist principle of dependent origination and the derived worldview have enriched the peace research in its fundamental design. Peace research has become more an ongoing process requiring corroboration from a wide range of perspectives, a series of "many small but coordinated 
efforts along several dimensions at the same time, starting in all kinds of corners of material and spiritual reality," instead of single-shot research on time and place-specific events, because the system would "hit back in a complex web of interrelations" (Galtung, 1993: 24). And in order to capture the constant changing in the multi-causal conditions, he emphasizes the necessity of making regular dialogues between all the parties involved, on the international and non-government organizational levels, rather than inter-group negotiation with the imminent threat of war on the side. As the world is gradually entering "a new era of cooperative politics and international conflict resolution" (Galtung, Jacobsen, \& Brand-Jacobsen, 2002: 70), the Buddhist emphasis on process and the ever-changing, interdependent nature of the reality have inspired peace builders and scholars to discover innovative means to peace and strengthened the confidence in their daily work on advancing direct and indirect causes of peace.

\section{- Peace by Peaceful Means}

With the shifting emphasis from results to causes/process, the notion of "peace by peaceful means," longtime valued among peace-makers, is rejuvenated with more persuasion from the perspective of Buddhism. Substantialized in the light of the principle of dependent origination, not only does the old belief "violence begets violence" become a mandate to prevent the destructive pattern of accelerated violence, but the impact and the ramifications of the peaceful means employed in the process would eventually contribute to peace. The peaceful means, in the Buddhist eyes, must include both the external behaviors and campaigns, and the inner state of mind of the peace activists. While the nonviolence resistance has been widely adopted by people working for peace, negative feelings and conflicts may exist within and between the peace-making groups. Moreover, the strong attachment to particular views, which is considered one of the two undesirable habits of mind in Buddhism, may further enhance an attitude of selfrighteousness not only in confronting violence and injustice, but when interacting with one's own comrades, which usually conduces to dissatisfaction, impatience and, hence, anger and resentment. A constant, regular reflection upon our own thoughts and feelings would serve as the first step to purge those of the negative and unproductive nature out of us and thus we would be able to pursue our quest for peace with peaceful means, internally and externally.

Besides, anger and other negative emotions at times could be so strong and overwhelming that one might forget the interdependent nature of all the phenomena. As a member of the human race, we all contribute directly or indirectly, with action or inaction, to violence, be it war, conflict, or exploitation. This realization unveils the share we have in participating in the web of violence, and hence could weaken the "us" versus "them", the "good guys" versus "the bad guys" dichotomy in minds of many peace makers and allows them to face the adversary with a more inclusive, understanding attitude, thus opening to more creative non-violent alternatives of promoting peace, a genuine peace by peaceful means.

\section{- The Holistic Framework of Peace and the Micro/Macro Linking Within}

Also derived from the principle of dependent origination and the interconnected worldview is a holistic view of peace and the micro/macro linkage between violence at all levels, which has perhaps the most potential among all Buddhist contributions in influencing peace research and peace activism. While peace studies has been characterized as interdisciplinary since its inception, the boundaries or conceptual frames of different academic disciplines inevitably compartmentalize the study of peace. And the study of violence at different levels has never been balanced in significance to the public as well as financial funding received. For example, criminal violence is more extensively investigated than violence against women and children, while the latter, in turn, has accrued more attention than the consequences of various forms of violence upon the collective public health (Turpin \& Kurtz, 1997). 
In the Buddhist conception of peace, all causes of violence and peace are interrelated and mutually influential; and the interrelations between violence at all levels are assumed and hence demands a multi-lateral comprehensive approach to stopping violence and promoting peace at all levels. One recent common trend in research on peace and violence is to explore the links between interpersonal, collective, national, and global levels of violence. An increasing number of scholars (Alexander et al., 1987; Brock-Utne, 1997; Galtung \& Ikeda, 1995; Kurtz \& Turpin, 1989; Reardon, 1993) have attempted to posit a relationship between the causes of peace and violence at the micro level and those at the macro level. Their work has certainly further illuminated the micro-macro linkage between different levels of peace and violence.

The relationship between direct, structural and cultural violence also entered the research agenda of peace and violence studies. Witnessing the horrible brutality pervasive in modern societies during his forty years of research on war and international conflicts, Galtung contends that the domestic policy on violence would be reflected in a nation's foreign policy, and "the family in general and marriage in particular are tests we must pass in order to contribute to peace in the larger setting of world society" (Galtung \& Ikeda, 1995: 24). The violence against women in so-called peace time and during the war (Boulding, 1992 \& 2000; Tickner, 1992), the economic exploitation in the domestic society as well as the international society (BrockUtne, 1997; Loy, 2002), religious tolerance for or even endorsement of use of violence as the most efficacious solution to the problem (Ellison \& Bartkowski, 1997; Gilligan, 1990; Gamson, 1984), all lead scholars to reexamine the concepts of peace, equality, national security and social harmony in a more holistic framework. Their research findings echo the claim of the micro-macro linkage of violence at all levels, and the claim that the inequitable social arrangements and cultural value systems produce harm upon the less privileged people even in the absence of physical and verbal violent behaviors. The notion of peace equaling the absence of direct violence or war is only temporary and fragile since many people still suffer from the injustice and violence legitimized in the inappropriate political, economical, and social institutions rooted in existing values, or ideologies. That is exactly what the Dalai Lama (1989) asserts in his inaugural speech of the Noble Peace Prize: absence of war is not true peace while many still suffer from poverty and human rights abuses. Only multilateral peace making efforts conceptualizing causes and consequences of violence as connected and interrelated along the micro/macro continuum under the holistic model of peace would afford the genuine, positive peace in the world.

To further actualization of the multi-level organic notion of peace in human society, the Buddhist emphasis on inner transformation of a person's state of mind and its cosmic scope in conceptualizing harmony finally completes the holistic model of peace. Reflecting upon negative feelings and thoughts within oneself as well as applying the insight to the real life conditions adds an intra-personal level to peace movement and peace education. Once recognizing the diverse and usually contradictory feelings and thoughts rising and disappearing within our own minds and their possible manifestations at the behavioral level, we would be more likely to be tolerant and patient and therefore in a better position to deal with the vast range of diversity out there in the world that might come into conflict with us, or with one another. On the other hand, the holistic framework Buddhism employs to explain the human existence would lead us to seek harmonious coexistence with others. Between humans and the nature, the Buddhist view of natural environment as a result of our collective doings in the past results in a sense of imminence which entails a feeling of obligation in seeking harmony since we all participate in either destruction or protection of the nature. The scale of the universe and the sense of awe implied in the notion of the Indra's Net, coincided with the modern astronomical discoveries, compel us to rethink the common ground we share as human beings living on this one planet (among billions of billions), which makes it easier to transcend our differences on the way to create a culture of peace. 


\subsection{Future Strategies}

The potentials that these perspectives and practices that Buddhism may enrich the fields of peace studies and peace activism of course certainly merit further investigation in theories as well as in practicum. Along with the longtime criticism of Buddhism as a passive and individualistic religion which encourages people to withdraw from the real world (for a review of criticisms, see Queen, 2000), over-emphasis on the role of inner transformation and the widening circle of individual influence as approaches to peace in larger contexts may seem slow and procrastinating in the eyes of those who consider immediate effort is needed in working for social justice and conflict intervention. Whereas the compassion and lovingkindness cultivated within individuals can certainly be necessary for transformation into a new culture of peace, specific areas of problem, such as class/race oppression and environmental degradation need to be adequately addressed and fully explored.

The introduction of the concept of nirvana into the West since the early days may also cause misunderstanding of peace as the ultimate existence in Buddhism. In some Buddhist branches, the state of nirvana equals with ultimate peacefulness (Jayatilleke, 1969), or it is considered as an ultimate solution for conflicts (Galtung, Jacobsen, \& Brand-Jacobsen, 2002). Since nirvana is extremely difficult to attain for almost all Buddhists, the equation (peace = nirvana) renders peace a remote, unattainable label that would not be conducive to any present peacemaking efforts. Along the same line of thinking, interpreting "right concentration" (one of the Noble Eightfold Path) as being peace would be easily misunderstood to be that one can only stay in peace on the meditation mat, if without adequate background in the Buddhist traditions. These two cases would call for greater efforts in trying to translating Buddhist concepts into peace studies.

Besides the problems of modern interpretations and translations across cultures and languages, in practice, the Buddhist monastic orders are often criticized as ingratiating themselves with authorities in exchange with advantages (Galtung, 1993; Sivaraksa, 1999). A group aiming at liberating self and others could in this world turn out to be part of the oppressive structure. Together with the fact that violence and conflicts still exist in countries where Buddhism is the state or majority religion (Little, 1994), the relations between Buddhism, political authorities, and nationalism as well as discrepancies between the Buddhist doctrine and its manifestations would need to be carefully observed and further studied, if an integrated model of peace is to be realized.

\section{Concluded Remarks}

This research paper examines the Buddha's fundamental teachings that contribute to peacebuilding and peacekeeping in the world. A Buddhist worldview based on the principle of dependent origination, its analysis of the causes of conflicts and violence, and the open communication and participatory decision-making procedures in social organizations, would inform and provide useful paths for theoretical approaches and research-based applications in peace studies. In particular, the Buddhist observation and reflection techniques developed for more than 2,500 years may start an "inner revo lution" (Thurman, 1998) among warring people as well as peace activists: enabling them to see more clearly the multilateral forces operating in the situation, and reexamining the appropriateness of own causes and behaviors. The true value of nonviolence, compassion and altruism advocated by Buddhism would also inspire all people on the path of peace. Given the will, the insight, the perseverance, and the proactive creativity to realize the infinite possibilities latent in the dependently originated reality, peace, from the Buddhist perspective, is realistic and achievable; and, aiming at making a more just and humane world, peacemaking is an imminent, common responsibility mandated by the interdependent nature of our existence and therefore to be shared by every one of us. 


\section{References}

Alexander, Jeffrey C., Berhard Giesen, Richard Munch, and Neil J. Smelser, eds. 1987. The Micro-Macro Link. Berkeley: University of California Press.

Blumberg, Herbert H. 1998. "Peace Psychology after the Cold War: A Selective Review." Genetic, Social and General Psychology Monograph, Vol.124, No.1, pp. 5-37.

Boulding, Elise. 1992. The Underside of History: A View of Women through Time. Newbury Park, CA: Sage.

Boulding, Elise. 2000. Cultures of Peace: The Hidden Side of History. Syracuse, NY: Syracuse University Press.

Brock-Utne, Birgit. 1997. "Linking the Micro and Macro in Peace and Development Studies. In Jennifer Turpin and Lester R. Kurtz, eds., The Web of Violence: From Interpersonal to Global (pp. 149-160). Urbana: University of Illinois Press.

Buddhist Scriptures. 1959. Translated by Edward Conze. London: Penguin.

Cabezón, José Ignacio. 1999. "The UNESCO Declaration: A Tibetan Buddhist Perspective." In David W. Chappell, ed., Buddhist Peace Work: Creating Cultures of Peace (pp. 183-188). Boston, MA: Wisdom Publications.

Chappell, David W., ed. 1999. Buddhist Peacework: Creating Cultures of Peace. Boston, MA: Wisdom Publications.

Chappell, David W. 2003. "Buddhist Social Principles.” In Kathleen H. Dockett, G. Rita Dudley-Grant, and C. Peter Bankart, eds., Psychology and Buddhism: From Individual to Global Community (pp. 259-276). New York: Kluwer Academic/Plenum Publishers.

His Holiness the Dalai Lama. 2002. "The Global Community and the Need for Universal Responsibility," International Journal of Peace Studies, vol. 7, no. 1, Spring/Summer. <http://www.gmu.edu/academic/ijps/vol7_1/Lama.htm> Accessed 8 November 2005.

His Holiness the Dalai Lama. 2001. "The Human Approach to World Peace", Peace and Conflict Studies, vol. 8, no. 2, November. <http://www.gmu.edu/academic/pcs/ DL82PCS.htm> Accessed 8 November 2005.

His Holiness the Dalai Lama. 1989. "Nobel lecture by His Holiness Tenzing Gyatso, the fourteenth Dalai Lama of Tibet." News Tibet, Vol. 23, No. 2, pp. 4-6.

De, Gokuldas. 1955. Democracy in Early Buddhist Sangha. Calcutta: University Press.

Ellison, Christopher G., and John P. Bartkowski. 1997. "Religion and Legitimization of Violence: Conservative Protestantism and Corporal Punishment." In Jennifer Turpin and Lester R. Kurtz, eds., The Web of Violence: From Interpersonal to Global (pp. 45-68). Urbana: University of Illinois Press.

Galtung, Johan. 1993. Buddhism: A Quest for Unity and Peace. Honolulu: Dae Won Sa Buddhist Temple.

Galtung, Johan. 1990. "The Path toward Peace Lies in Dialogue and Action." Seikyo Times, No. 348, 43-46.

Galtung, Johan, and Daisaku Ikeda, 1995. Choose Peace: A Dialogue between Johan Galtung and Daisaku Ikeda. London: Pluto Press.

Galtung, Johan, Carl G. Jacobsen, and Kai Frithjof Brand-Jacobsen. 2002. Searching for Peace: The Road to Transcend (2nd ed.). London: Pluto Press. 
Gamson, William. 1984. "Political Symbolism and Nuclear Arms Policy." Paper presented at the annual meeting of the American Sociological Association, 21-23 August, San Antonio, Texas.

Gilligan, John J. 1990. “Teaching Peace in a Christian Context.” In Leroy S. Rouner, ed.,

Celebrating Peace (pp. 15-32). Notre Dame, IN: University of Notre Dame Press. Hirakawa, Akira, ed. 1997. Bukkyo kanbon daijiten (Buddhist Chinese-Sanskrit Dictionary). Tokyo: The Reiyukai.

Hopkins, Jeffrey. 2000. The Art of Peace: Nobel Peace Laureates Discuss Human Rights, Conflict and Reconciliation. Ithaca, NY: Snow Lion.

Herskovits, Annette. 2002. "What Future for Tibet?" Turning Wheel (A Publication of the Buddhist Peace Fellowship), Winter 2002-2003, p. 5.

Jayatilleke, Kulatissa Nanda. 1969. Buddhism and Peace. Kandy, Ceylon: Buddhist Publication Society.

Khongchinda, Phramaha Chanya. 1993. The Buddha's Socio-Political Ideas. New Delhi: Navrang.

Kraft, Kenneth. 1995. "Practicing Peace: Social Engagement in Western Buddhism." Journal of Buddhist Ethics, No. 2, pp. 152-177.

Kurtz, Lester R., and Jennifer E. Turpin. 1989. "The Social Psychology of Warfare." In Lester R. Kurtz, ed., The Nuclear Cage: A Sociology of the Arms Race (pp. 77-89). Englewood Cliffs, NJ: Prentice-Hall.

Lawler, Peter. 1995. A Question of Values: Johan Galtung's Peace Research. Boulder and London: Lynne Rienner Publishers.

Little, David. 1994. Sri Lanka: The Invention of Enemy. Washington D.C.: United States Institute of Peace Press.

The Long Discourses of the Buddha: A Translation of the Digha Nikaya. 1995. Translated from the Pali by Maurice Walshe. Boston, Massachusetts: Wisdom Publications.

Loy, David R. 2002. A Buddhist History of the West: Studies in Lack. Albany, NY: State University of New York Press.

Macy, Joanna.1983. Despair and Personal Power in the Nuclear Age. Philadelphia, PA: New Society Press.

The Middle Length Discourses of the Buddha: A Translation of the Majjhima Nikaya, 2nd edition. 2001. Translated by Bhikkhu Ñanamoli and Bhikkhu Bodhi. Boston, Massachusetts: Wisdom Publications.

Myers, David G. 1999. Social Psychology (6th ed.). Boston, MA: McGraw-Hill.

"Peace: How realistic is it? Views from Abroad." 2003. Tricycle, Vol. 12, No. 4, Summer, pp. 73-77.

Powers, John. 2000. "The Free Tibet Movement: A Selective Narrative." In Christopher S. Queen, ed., Engaged Buddhism in the West (pp. 218-244). Boston, MA: Wisdom Publications.

Ogiwara Unrai [A.k.a., Wogihara Unrai], ed. 1979. Bon-Wa dai jiten [originally subtitled: The Sanskrit-Chinese Dictionary of Buddhist Technical Terms based on the Mahavyutpatti]. 
Revised ed. Tokyo: Suzuki Gakujutsu Zaidan. Queen, Christopher S., ed. 2000. Engaged Buddhism in the West. Boston, MA: Wisdom Publications.

Rahula, Walpola. 1974. What the Buddha Taught (2nd ed.). New York: Grove.

Reardon, Betty A. 1993. Women and Peace: Feminist Visions of Global Security. Albany, NY: State University of New York Press.

Schilling, Dianne. 1993. Getting Along: Activities for Teaching Cooperation, Responsibilities, Respect. Spring Valley, CA: Inner choice Publishing.

Schroeder, Judy. 1995. Peace Talks: Classroom Activities to Enhance Communication and Conflict Resolution Skills. Louisville, KY: Peace Education Program, Inc.

Schumacher, E. F. 1975. The Small is Beautiful. New York: Harper and Row.

Shih Yi n-shun. 1980. "Fofa yu renlei heping (Dharma and Human Peace)" In Fojiao yu zhengzhi (Buddhism and Politics). Taipei: Dasheng wenhua.

Shih Sheng-yen. 1999. “A Pure Land on Earth.” In David W. Chappell, ed., Buddhist Peacework: Creating Cultures of Peace. Boston, MA: Wisdom Publications. Sivaraksa, Sulak. 1999.

"Buddhism and a Culture of Peace." In David W. Chappell, ed., Buddhist Peacework: Creating Cultures of Peace (pp. 39-46). Boston, MA: Wisdom Publications.

Sivaraksa, Sulak. 1992. Seeds of Peace: A Buddhist Vision for Renewing Society. Berkeley, CA: Parallax Press.

Stewart, Jon. 2002. "On the Far Side of Revenge: An Interview with Paul Haller on Northern Ireland." Turning Wheel (A publication of the Buddhist Peace Fellowship), Winter 20022003, pp. 16-19.

Sumanatissa, Medagoda. 1991. "Buddhism and Global Economic Justice." In Glenn D. Paige and Sarah Gilliatt, eds., Buddhism and Nonviolent Global Problem-Solving (pp. 125-135).

Honolulu, Hawai'i: Center for Global Nonviolence Planning Project, Spark M. Matsunaga Institute for Peace, University of Hawai'i. Taisho shinshu Daizokyo (The Tripitaka, new compilation of the Taisho era).

Thich Nhat Hanh. 2003. Creating True Peace: Ending Violence in Yourself, Your Family, Your Community, and the World. New York: Free Press.

Thich Nhat Hanh. 1999. "Ahimsa: The Path of Harmlessness." In David W. Chappell, ed. Buddhist Peacework: Creating Cultures of Peace. Boston, MA: Wisdom Publications.

Thurman, Robert A. F. 1998. Inner Revolution. New York: River-head.

Tickner, Ann J. 1992. Gender in International Relations: Feminist Perspectives on Achieving Global Security. New York: Columbia University Press.

Turpin, Jennifer, and Lester R. Kurtz, eds. 1997. The Web of Violence: From Interpersonal to Global. Urbana: University of Illinois Press. 